\title{
Understanding 3G Mobile Service Acceptance in Ho Chi Minh City, Vietnam
}

\author{
Phuong V. Nguyen ${ }^{1}$, Phuong M. To ${ }^{1}$, Van T. T. Bui ${ }^{1} \&$ An T. H. Nguyen ${ }^{1}$ \\ ${ }^{1}$ School of Business, Ho Chi Minh International University, VNU-HCMC, Vietnam \\ Correspondence: Phuong V. Nguyen, School of Business, Ho Chi Minh International University, VNU - HCMC, \\ Vietnam. Tel: 848-3724-4270. E-mail: nvphuong@hcmiu.edu.vn
}

Received: January 19, 2015

Accepted: February 6, 2015

Online Published: March 27, 2015

doi:10.5539/ijbm.v10n4p70

URL: http://dx.doi.org/10.5539/ijbm.v10n4p70

\begin{abstract}
The rapid development of telecommunication and Internet services enables smartphone users to access online services faster and create more demand for using high-speed data services. The third generation $(3 \mathrm{G})$ mobile services have become the pioneer for the trend of high speed data transmission for years. This study aims to explore the factors that affect behavioral intention of adopting $3 \mathrm{G}$ mobile telecommunications. After implementing a structural equation modeling to analyze the data collection of 223 self-administered correspondents, we found that perceived factors, including ease of use, usefulness and enjoyment have a significantly positive relationship with attitude and while the attitude is positively associated with behavioral intention to use 3G. Based on the results, the research enables us to propose several practical recommendations to $3 \mathrm{G}$ providers in Vietnam such as $3 \mathrm{G}$ providers should provide more interesting and entertaining contents in their $3 \mathrm{G}$ applications and services, which charge appropriate fees and are easy to use for customers. In addition, $3 \mathrm{G}$ providers should focus on customers' attitude by listening and receiving customers' feedbacks to improve $3 \mathrm{G}$ technological solutions and value-added services.
\end{abstract}

Keywords: 3G, behavioral intention, Vietnam, mobile service

\section{Introduction}

Nowadays, the rapid development of the Internet and wireless technologies drives to increase in high demand for users of faster data transmission. Consumers need high-speed data services for their smartphones, tablets or laptops so that they can access the Internet to implement a variety of online activities efficiently with more convenient ways. In the situation with high technology for connection of mobile phone, $3 \mathrm{G}$ technology has been the pioneer for the trend of high-speed data transmission for years.

$3 \mathrm{G}$ is the third generation of mobile telecommunications technology, which is a set of standards used in mobile devices, telecommunication services and networks that complies with the International Mobile Telecommunications-2000 (IMT-2000) specifications by the International Telecommunication Union. 3G network provides faster data rates than the previous generation networks $(1 \mathrm{G}$ and $2 \mathrm{G}) .1 \mathrm{G}$ regarded as the first generation operating analog technology provides a wide area low bandwidth just less than $10 \mathrm{kbps}$ (kilobyte per second) in 1940s. At that time, only voice service was used. 2G stands for the second generation, established in the 1990s, provides data rates only between 10 and $20 \mathrm{kbps}$. Consumers used $2 \mathrm{G}$ for performing both voice communication and short message service (SMS) (Campbell \& Schwartz, 2001). In the early stage of 3G mobile network, it can offer data rates of $144 \mathrm{Kbps}$ for fast-moving mobile users in vehicles, $384 \mathrm{Kbps}$ for slower moving pedestrian users, and $2048 \mathrm{kbps}$ from fixed locations. However, $3 \mathrm{G}$ network system now can provide up to 14.4 Mbps transmission speeds with Universal Serial Bus (USB) 3G and enhance more diverse applications. Therefore, 3G mobile services become more and more widespread around the world with various applications brought to users of cellphones, smartphones, tablets and laptops with a huge variety of Internet services such as online music, online video, online game, video call, GPS, social networks and so forth.

Although other countries accepted $3 \mathrm{G}$ very soon, in Vietnam, the government has allowed providing 3G mobile services since 2009, which was the milestone in history of mobile network in Vietnam. However, the number of $3 \mathrm{G}$ users was still low at that time. The reason was that subscribing fee for $3 \mathrm{G}$ mobile services at that time was rather expensive and the telecom infrastructure for $3 \mathrm{G}$ technology had not developed completely to be ready to use. The situation has much more improved since 2012. According to the research of Nielsen above, in general, 
3G has been fairly successful in Vietnam, especially the significance growth rate of 3G customers since 2012 . Although there have been some problems existing such as high monthly charges and limited applications, many analysts believe that $3 \mathrm{G}$ market in Vietnam has many opportunities for developing, especially in content services and Internet-based services. Despite the successes and potentials of $3 \mathrm{G}$ mobile services in Vietnam, 3G customers are still not satisfied about service quality of network systems, which are becoming degraded for crowded users, fewer promotion programs and not good customer services of $3 \mathrm{G}$ providers. The development of $3 \mathrm{G}$ will become more dramatically if $3 \mathrm{G}$ providers solve current problems and continue to exploit new potentials of $3 \mathrm{G}$ services.

According to the situation of $3 \mathrm{G}$ market in Vietnam, investigating about acceptance of $3 \mathrm{G}$ with the view of Vietnamese consumers is really necessary. The main reason is that it will help $3 \mathrm{G}$ providers understand customers' perception more clearly as well as help them know which elements actually influence customers' decision to accept $3 \mathrm{G}$ mobile services. As a result, they will have good strategies to improve their service quality and attract more customers to accept $3 \mathrm{G}$ services as well as create loyalty customers.

In fact, the acceptance of $3 \mathrm{G}$ is not simple, and it is not just a matter of whether customers adopt or not adopt the technology, but it comprises many reasons that led to the acceptance and subscription (Chong, Darmawan, Ooi, \& Lee, 2010). In this research, we replicated and modified previous research models to investigate what factors affect the intention to use $3 \mathrm{G}$. Our model aims to test 5 main factors, including perceived usefulness (PU), perceived ease of use (PEOU), perceived enjoyment (PE), attitude (ATT) and behavioral intention to use (BITU). Specifically, we add demographic profile of respondents considered as control variables to the research model. By using structural equation modeling to test the research model, we find that PEOU has a strongly positive impact on PE, following on Attitude and then on PU. The findings are generally consistent with some previous studies. The results also illustrate that PU and PE have no direct effects on BITU, but they are positively associated with attitude, in turn; attitude has a strongly positive relationship with BITU. Specifically, the demographic variables have no significant correlation with BITU. The next section presents theoretical backgrounds and formulation of research hypotheses. The third section describes the research methodology with data analysis and estimated results. Discussions will be presented in section 4. Lastly, the fifth section summarizes our main findings and suggests some recommendations for $3 \mathrm{G}$ providers.

\section{A Brief Literature Review}

\section{$2.13 G$ Mobile Services}

The International Telecommunication Union (ITU) defined 3G of mobile telephony standards known as International Mobile Telecommunications-2000 to facilitate growth, increase bandwidth up to $14.4 \mathrm{Mbps}$ transmission speeds and enhance more diverse applications. With its broader bandwidth, greater data speeds, increased capacity for packet voice and data, 3G creates new methods for cell phone users to communicate, assess information, implement new business and learn models such as online shopping and training, and mobile gaming and television.

Three main cell phone providers (MobiFone, Vinaphone, \& Viettel) have introduced 3G in Vietnam since December of 2009. According to statistics of Ministry of Information and Communications of Vietnam, there are around 138.6 cellular subscribers and 27.5 million $3 \mathrm{G}$ subscribers by the end of 2014. Although the telecommunication industry in Vietnam has reformed through open this market for new entrants, three main providers still dominated the market. Specifically, by the end of 2013, Viettel accounted for $34.73 \%$ of the $3 \mathrm{G}$ market, the largest share of total 3G subscribers; the followers are MobiFone and Vinaphone with 33.19\% and $29.71 \%$, respectively. A number of $3 \mathrm{G}$ customers will increase in the future because $3 \mathrm{G}$ services are playing an important part of their daily life. Therefore, it is essential to understand what main factors that influence Vietnamese consumers' intention to use $3 \mathrm{G}$ mobile services are.

\subsection{Factors Influence the Adoption of $3 G$}

Many previous studies have developed Technology Acceptance Model (TAM) of Davis (1989) to examine factors that influence customers' decision to adopt 3G technology. For instance, Liao et al. (2007) illustrated that Perceived Usefulness (PU) and Perceived Ease of Use (PEOU) have a positive impact on attitude, which, in turn, influence behavioral intention. Additionally, they also showed Perceived Enjoyment (PE) played a major and essential role in users' acceptance of $3 \mathrm{G}$ services. Similarly, some other studies extended the TAM to investigate the relationship between PE with attitude, and in turn, behavioral intention to accept hand-held Internet devices (Bruner and Kumar, 2005) or to adopt a hedonic information system (Van Der Hejiden, 2004). In another study, Chong et al. (2012) extended the TAM to incorporate demographic profile of users. They found that there is no difference in gender and age as using $3 \mathrm{G}$ services. However, customers with a higher educational level are more 
likely to adopt $3 \mathrm{G}$.

In fact, the TAM is one of the most commonly conducted models to explore information technology (IT) acceptance. In this paper, we extend the model of Liao et al. (2007) to examine what factors influence Vietnamese consumers to use 3G mobile services. According to the TAM, PEOU is defined as the "the degree to which a person believes that using a particular system would be free of effort." From empirical studies, PEOU was considered as an essential factor that affects the acceptance of information technology (Igbaria, Livari \& Maragahh, 1995). PEOU was also viewed as "the individual's perception of how easy the innovation is to learn and to use," as a result of investigating employees' decisions to use computers (Venkatesh, 2000). In general, the relationships between PEOU with PU and ATT have been empirically recognized in the IT literature. Some studies showed their findings were consistent with TAM results; that is, PEOU and PU have a positive relationship with attitude (Burton-Jones \& Hubona, 2005; Igbaria et al., 1997).

Davis (1989) defined PU as "the prospective user's subjective probability that using a specific application system will increase his or her job performance within an organizational context." Adams et al. (1992) reported that PU drove users to adopt computer systems. Other studies have also demonstrated that PU is possibly relevant with system usage (Thompson et al., 1991; Igbaria et al., 1994). In terms of relationship between PU and attitude, some prior studies illustrated that the more usefulness of adopting a new technology; the greater potential customers would like to use it (Hung et al., 2003; Yang, 2005; Liao et al., 2007.)

Moon and Kim (2001) consider PE as a driven force of motivation in the technology acceptance process, implying that the implementation of an activity of adopting technology is perceived to be enjoyable. In fact, many entertainment activities provided by $3 \mathrm{G}$ mobile services are fun and enjoyable for subscribers such as online games, mobile TV, online music, e-books, and so on. The authors demonstrated that PE is positively associated with attitude towards using a specified source. Besides, Liao et al. (2007) also found out a consistent result.

The TAM posits that real usage of a particular system will be identified by a person's behavioral intention, which is jointly identified by a person's attitude towards adopting a system (Liao et al., 2007). In addition, based on a concept of attitude of Ajzen and Fishbein (1980), Robinson, Marshall \& Stamps (2005) developed the measures of attitude. Moon and Kim (2001) also used the similar measures of attitude toward the research about the acceptance of World Wide Web (WWW). Furthermore, more extensive meanings of attitude were used to measure attitudes toward different technologies by other researchers. Attitude measures consisting of consumers' perceptions of convenience, time and money saving, security and risks, and social contact were determined and demonstrated through a study of Chen et al. (2002). Yu et al. (2005) conducted the research measuring attitude toward T-commerce by asking consumers' interests to the service and product information and perception.

Behavioral intention (BI) to use can be considered as a measure of the likelihood that a person will adopt the application meanwhile the TAM uses actual usage in order to represent a self-report calculation of time or frequency of adopting the application (Davis et al., 1989). However, in reality, it is too difficult to acquire an objective measurement of a user's intention to disclose his or her behavior. Several studies have proven that both theoretical and empirical results exist for the strong relationship between intention to engage in a behavior and actual behavior (Dabholkar and Bagozzi, 2002; Vijayasarathy, 2004). In this study, we define behavioral intention is considered as a customer's intention to use $3 \mathrm{G}$ mobile services.

Based on the literature review, we posit the following hypotheses:

H1: PEOU positively affects $P U$ of $3 G$ mobile services.

H2: PEOU has a positive effect on attitude towards using $3 G$ mobile services.

H3: PEOU has a positive impact on PE of $3 G$ mobile services.

H4: $P U$ positively affects attitude towards using $3 G$ mobile services.

H5: $P U$ has a positive effect on behavioral intention to use $3 G$ mobile services.

H6: PE positively affects attitude towards using $3 G$ mobile services.

H7: PE has a positive impact on behavioral intention to use $3 G$ mobile services.

H8: $P E$ has a positive effect on $P U$ of $3 G$ mobile services.

H9: Attitude positively affects behavioral intention to use $3 G$ mobile services.

In addition, we add demographic profile of respondents including age and gender considered as control variables.

Figure 1 presents a research model. 


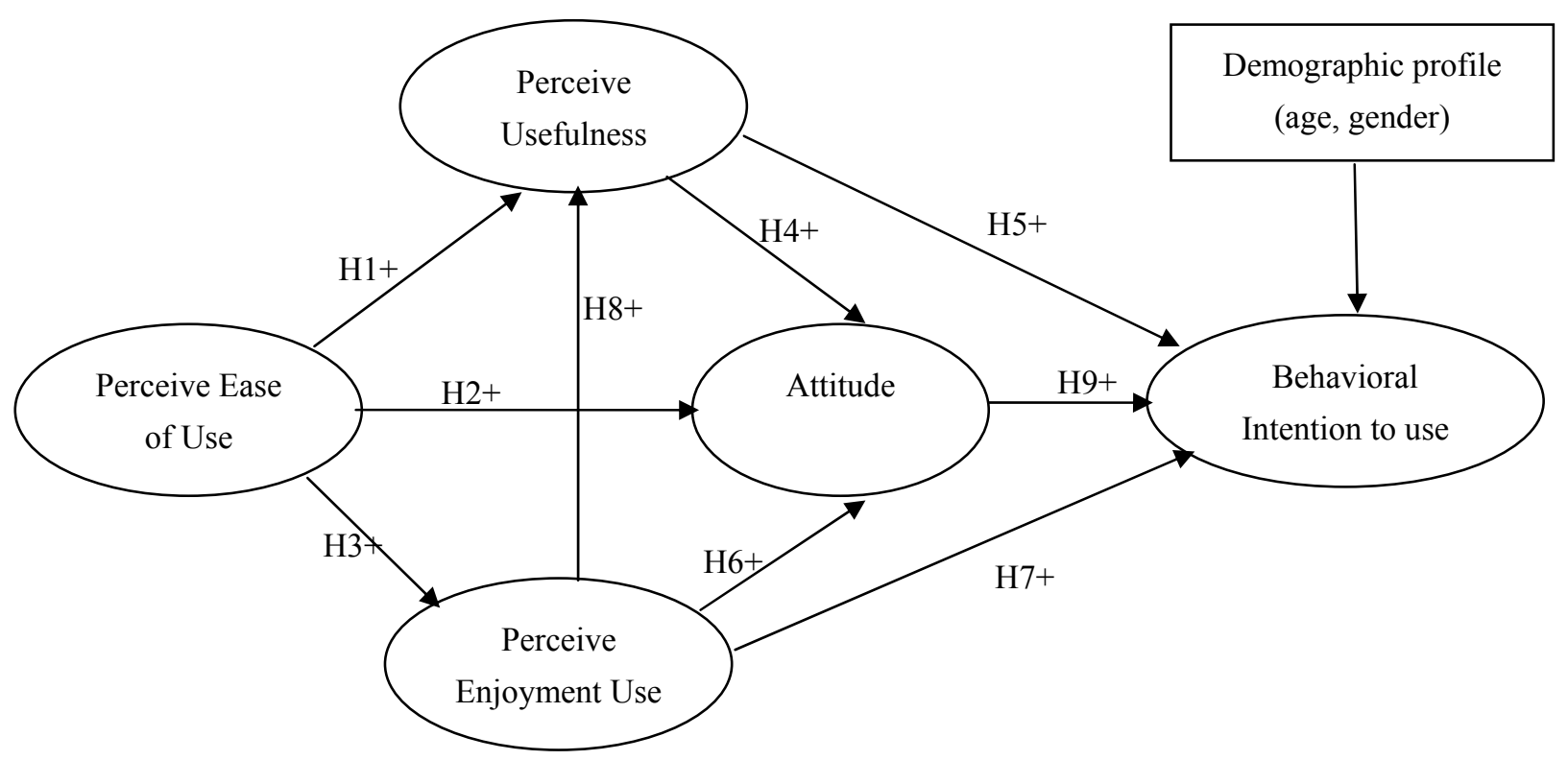

Figure 1. Research model

\section{Method}

We developed a survey questionnaire by following from previous measurement scales and translating into Vietnamese language, which makes respondents more comfortable. We conducted in-depth interviews with 15 persons who have been using $3 \mathrm{G}$ services to ask for reading the questionnaire and giving their feedbacks. The aim of this pilot test was to clarify the structure and content of the questionnaire as well as modify it appropriate in the Vietnamese context, which guaranteed that the questionnaire was clear and understandable before distribution of the questionnaire to respondents, who were living or working at Thu Duc district, Ho Chi Minh City (HCMC), Vietnam. According to the Statistic Office of HCMC in 2011, the total population of Thu Duc has 474.547 with 12 wards.

The questionnaire was designed to ask for respondents' acceptance and intention towards using $3 \mathrm{G}$ mobile services. We distributed the questionnaire directly to respondents and collected right after filling in it during two months from March to April of 2013 at 28 cafeterias close to the office buildings and Vietnam National University campuses in Thu Duc district. Concerning the minimum sample size requirements, there exists different points of view in previous researches about how large a sample could be to avoid bias and truly reflect the research situation. According to Anderson and Gerbing (1984) in their research about the suitable sample size for confirmatory factor analysis conducted in 1984, the sample size of 150 is enough for the result and the convergent process to be appropriate. After discarding 77 invalid responses, there were 223 qualified responses for analysis.

Table 1 presents some demographic characteristics of the respondents. The female respondents accounted for 53.4 percent (119 persons), and the rest was male. Moreover, 58.7 percent (131 respondents) were from 18 to 25 years old. Regarding occupation, the majority of the respondents was undergraduate students with 52 percent (116). 
Table 1. Demographic characteristics of the respondents

\begin{tabular}{llll}
\hline Measure & Items & Frequency & Percentage \\
\hline \multirow{3}{*}{ Gender } & Male & 104 & 46.6 \\
& Female & 119 & 53.4 \\
Age & Under 18 & 36 & 16.1 \\
& From 18 to 25 & 131 & 58.7 \\
& From 26 to 35 & 31 & 13.9 \\
& From 36 to 45 & 15 & 6.7 \\
Obove 45 & 10 & 4.5 \\
Occupation & High school students & 34 & 15.2 \\
& Undergraduate students & 52 \\
Income & Office staffs & 116 & 27.4 \\
& Owners of business & 61 & 2.2 \\
& Others & 5 & 3.1 \\
& Under 2 million VND & 7 & 35.9 \\
& From 2 to 4 million VND & 80 & 32.7 \\
\hline
\end{tabular}

Source: Data.

Sample size $=223$. Exchange rate (on June, 2013) $=20,828.00 \mathrm{VND} / \mathrm{US} \$$.

The independent and dependent variables used for this study are adapted from the prior ones. Table 2 illustrates descriptive statistics of selected items for the respective constructs and references. The questionnaire includes three sections. The first part asks respondents about their personal information, which $3 \mathrm{G}$ provider they have registered with and which type of 3G's multimedia applications they have used. The second section contains 27 main statements evaluated on a five-point Likert scale where 1-strongly disagree to 5 -strongly agree. The last one is optional part which respondents can write their ideas about quality of $3 \mathrm{G}$ mobile services of their provider as well as their expectations to improve $3 \mathrm{G}$ services in the future.

\section{Results}

After processing data and analyzing demographic profile, factors and their indicators were illustrated in Table 2 . The PU has the means ranging from 3.61 to 3.89. The means of PEOU vary from 3.73 to 4.07 . The means of PE range from 3.61 to 3.74 . The means of attitude towards using $3 \mathrm{G}$ services range from 3.40 to 3.87 . Finally, the means of BITU vary from 3.65 to 3.81 .

Table 2. Descriptive statistics

\begin{tabular}{|c|c|c|c|}
\hline \multicolumn{2}{|c|}{ Measurement scale } & Mean & SD \\
\hline \multicolumn{4}{|c|}{ Perceived usefulness (Liao et al., 2007, Pagani, 2004; Chong et al., 2010; Kuo \& Yen, 2009) } \\
\hline PU1 & Using $3 \mathrm{G}$ saves me time & 3.74 & 1.014 \\
\hline PU2 & $3 \mathrm{G}$ increases the quality of communication & 3.69 & 0.953 \\
\hline PU3 & $3 \mathrm{G}$ provides many necessarily useful services and applications in life & 3.89 & 0.837 \\
\hline PU4 & $3 \mathrm{G}$ supports my life easier & 3,77 & 0.900 \\
\hline PU5 & The quality of my life is improved somehow thanks to using $3 \mathrm{G}$ & 3.61 & 0.862 \\
\hline \multicolumn{4}{|c|}{ Perceived ease of use (Liao et al., 2007; Teo \& Pok, 2003; Kuo \& Yen, 2009; Agarwal \& Prasad, 1997) } \\
\hline PEOU1 & It is simple and easy to register $3 \mathrm{G}$ for my mobile phone with providers & 4.00 & 0.937 \\
\hline PEOU2 & 3G-based services do not require many skills in order to get used to them & 3.98 & 0.918 \\
\hline PEOU3 & I learned to use $3 \mathrm{G}-$ based services quickly & 4.07 & 0.844 \\
\hline PEOU4 & 3G-based services are understandable and clear & 3.73 & 0.955 \\
\hline PEOU5 & I believe that it is easy to get $3 \mathrm{G}-$ based services do what I want them to do & 3.76 & 0.866 \\
\hline
\end{tabular}




\begin{tabular}{|c|c|c|c|}
\hline PEOU6 & In general, it is easy to use $3 \mathrm{G}$ based-services & 3.90 & 0.840 \\
\hline \multicolumn{4}{|c|}{ Perceived enjoyment (Chong et al., 2010; Liao et al., 2007) } \\
\hline PE1 & There are many fun and enjoyable 3G-based services & 3.74 & 0.921 \\
\hline PE2 & 3G-based services make me really curious about them & 3.73 & 0.896 \\
\hline PE3 & Using 3G-based services is a good way to entertain & 3.61 & 0.887 \\
\hline PE4 & $\begin{array}{l}\text { 3G-based services guide me explore novelty that is not found in previous-generation mobile } \\
\text { services }\end{array}$ & 3.64 & 0.864 \\
\hline PE5 & 3G-based services help me have fun time with my family and my friends & 3.74 & 0.922 \\
\hline \multicolumn{4}{|c|}{ Attitude towards using 3G (Vijayasarathy, 2004; Liao et. al, 2007) } \\
\hline ATT1 & $3 \mathrm{G}$ are really beneficial & 3.87 & 0.724 \\
\hline ATT2 & Fee of using $3 \mathrm{G}$ is acceptable & 3.40 & 1.030 \\
\hline ATT3 & Using $3 \mathrm{G}$ is a good idea & 3.75 & 0.787 \\
\hline ATT4 & Using $3 \mathrm{G}$ is worthy & 3.67 & 0.803 \\
\hline ATT5 & I have positive attitude with using $3 \mathrm{G}$ & 3.69 & 0.794 \\
\hline ATT6 & I highly evaluate values which $3 \mathrm{G}$ brings to me & 3.61 & 0.796 \\
\hline ATT7 & In general, I like using $3 \mathrm{G}$ for my mobile phone & 3.78 & 0.859 \\
\hline \multicolumn{4}{|c|}{ Behavioral intention to use (Liao et al., 2007; Chong et al., 2010) } \\
\hline BITU1 & I am always willing to use $3 \mathrm{G}$ for my mobile phone & 3.81 & 0.951 \\
\hline BITU2 & I intent to use $3 \mathrm{G}$ for my mobile phone in the future & 3.87 & 0.834 \\
\hline BITU3 & I will try new services of $3 \mathrm{G}$ in the future & 3.70 & 0.866 \\
\hline BITU4 & I will recommend my family and my friends to use $3 \mathrm{G}$ for their phones & 3.65 & 0.964 \\
\hline
\end{tabular}

Source: Data.

Exploratory factor analysis (EFA) is used to reduce unsuitable variables and establish a simple structure of variables. According to Hair et al. (1998), factor loading is a criterion to ensure practical significance of EFA. The factor loading is regarded as gaining the minimum level if it is greater than 0.3 , significance if it is greater than 0.4, and practical significance if it is larger than 0.5. Furthermore, we conduct the reliability test by calculating Cronbach's Alpha. Using Cronbach's Alpha aims to test the internal consistency reliability of measurement. Many researchers suggested that an alpha score of above 0.6 is generally acceptable (Slater, 1995; George \& Mallery, 2003). The Corrected Item-Total Correlations help to identify the degree to which each indicator correlates with the total score. Pallant (2007) illustrates that a value less than 0.3 implies that the item is measuring something different from the whole scale. The "Cronbach's alpha if deleted" is evaluated to identify the effect of removing items from each sub-scale (Lemmens, 2010). The item whose Cronbach's alpha if the item deleted is larger than the overall Cronbach's alpha, and corrected item total correlation is less than 0.3 will be eliminated from the variable list.

Table 3 demonstrates Cronbach's alpha for each construct identified and used. All Cronbach's alpha values range from 0.803 to 0.875 , which are greater than 0.6 are acceptable. As a result, the constructs are considered reliable and no item is deleted in this stage.

Table 3. Result of reliability test

\begin{tabular}{lll}
\hline Construct & Measurement items & Cronbach's alpha \\
\hline Perceived usefulness & PU1, PU2, PU3, PU4, PU5 & 0.839 \\
Perceived ease of use & PEOU1, PEOU2, PEOU3, PEOU4, PEOU5, PEOU6 & 0.875 \\
Perceived enjoyment & PE1, PE2, PE3, PE4, PE5 & 0.850 \\
Attitude & ATT1, ATT2, ATT3, ATT4, ATT5, ATT6, ATT7 & 0.869 \\
Behavioral intention to use & BITU1, BITU2, BITU3, BITU4 & 0.803 \\
\hline
\end{tabular}

Source: Data.

ATT1 was excluded from the measurement scale in the process of exploratory factor analysis (EFA). Implementing Confirmatory Factor Analysis (CFA) by using Analysis of Moment Structure (AMOS) is the next stage to identify the factor structure of the dataset. In the CFA, the factor structure which was extracted in the 
EFA is confirmed. Specifically, it is used to test whether the consistence between measures of a construct and a researcher's understanding about the nature of that construct (or factor) occurs. Clearly, the aim of confirmatory factor analysis is to examine whether the data fits the hypothesized measurement model.

At the first-round step at this stage, ATT2 was discarded because of its low weight of 0.458 , which is less than 0.5. After removing ATT2, the results of model-fit were acceptable: Chi-square $=311.819$; Chi-square $/ \mathrm{df}=1.223$ $(<5)$; Comparative Fit Index $(\mathrm{CFI})=0.979(>0.9)$; Goodness-of-fit index $(\mathrm{GFI})=0.901(>0.9)$; Tucker and Lewis Index $(\mathrm{TLI})=0.975(>0.9)$; Root Mean Square Error Approximation $($ RMSEA $)=0.032(<0.08)$

In terms of Standardized Regression Weights, there were all weights, exceeding 0.5 and all had statistical significance (all $\mathrm{p}=0.000<0.05$ ). Table 5 presents the results of measurement model test by using CFA. Moreover, Composite Reliability (CR) of all factors ranged from 0.805 to $0.884(>0.7)$ while Average Variance Extracted (AVE) ranged from 0.502 to $0.607(>0.5)$. Therefore, the measurement model meets criteria for convergent validity. The statistical results of standardized loadings, composite reliability, variance extracted are listed in table 4.

Table 4. Results of measurement model test by using confirmatory factor analysis

\begin{tabular}{|c|c|c|c|c|}
\hline Construct and indicators & $\begin{array}{l}\text { Standardized } \\
\text { Loadings }\end{array}$ & $\begin{array}{l}\text { Composite } \\
\text { reliability }\end{array}$ & $\begin{array}{l}\text { Variance } \\
\text { extracted }\end{array}$ & $\begin{array}{l}\text { Numbers } \\
\text { of Items }^{\mathrm{a}}\end{array}$ \\
\hline Perceived usefulness & & 0.835 & $\mathbf{0 . 5 0 7}$ & $5(5)$ \\
\hline PU1 & $0.700 * * *$ & & & \\
\hline PU2 & $0.758^{* * *}$ & & & \\
\hline PU3 & $0.828 * * *$ & & & \\
\hline PU4 & $0.633 * * *$ & & & \\
\hline PU5 & $0.619 * * *$ & & & \\
\hline Perceived ease of use & & 0.863 & 0.516 & $6(6)$ \\
\hline PEOU1 & $0.621 * * *$ & & & \\
\hline PEOU2 & $0.594 * * *$ & & & \\
\hline PEOU3 & $0.715^{* * *}$ & & & \\
\hline PEOU4 & $0.741 * * *$ & & & \\
\hline PEOU5 & $0.780 * * *$ & & & \\
\hline PEOU6 & $0.829 * * *$ & & & \\
\hline Perceived enjoyment & & 0.834 & 0.502 & $5(5)$ \\
\hline PE1 & $0.632 * * *$ & & & \\
\hline PE2 & $0.684 * * *$ & & & \\
\hline PE3 & $0.756^{* * *}$ & & & \\
\hline PE4 & $0.689 * * *$ & & & \\
\hline PE5 & $0.773 * * *$ & & & \\
\hline Attitude & & 0.884 & 0.607 & $5(7)$ \\
\hline ATT3 & $0.685^{* * *}$ & & & \\
\hline ATT4 & $0.861 * * *$ & & & \\
\hline ATT5 & $0.754 * * *$ & & & \\
\hline ATT6 & $0.727 * * *$ & & & \\
\hline ATT7 & $0.852 * * *$ & & & \\
\hline $\begin{array}{l}\text { Behavioral intention } \\
\text { to use }\end{array}$ & & 0.805 & 0.609 & $4(4)$ \\
\hline BITU1 & $0.693 * * *$ & & & \\
\hline BITU2 & $0.714 * * *$ & & & \\
\hline BITU3 & $0.718 * * *$ & & & \\
\hline BITU4 & $0.727 * * *$ & & & \\
\hline
\end{tabular}

Notes. ${ }^{a}$ Final items (initial items). ATT2 is excluded due to low weight $(<0.5) .{ }^{* *} \mathrm{p}<0.001,{ }^{* *} \mathrm{p}<0.01,{ }^{*} \mathrm{p}<0.05$. Fit statistics after purification process: Chi-square $=311.819 ;$ Chi-square $/ \mathrm{df}=1.223 ; \mathrm{CFI}=0.979 ; \mathrm{GFI}=0.901 ; \mathrm{TLI}=0.975 ; \mathrm{RMSEA}=0.032$. 


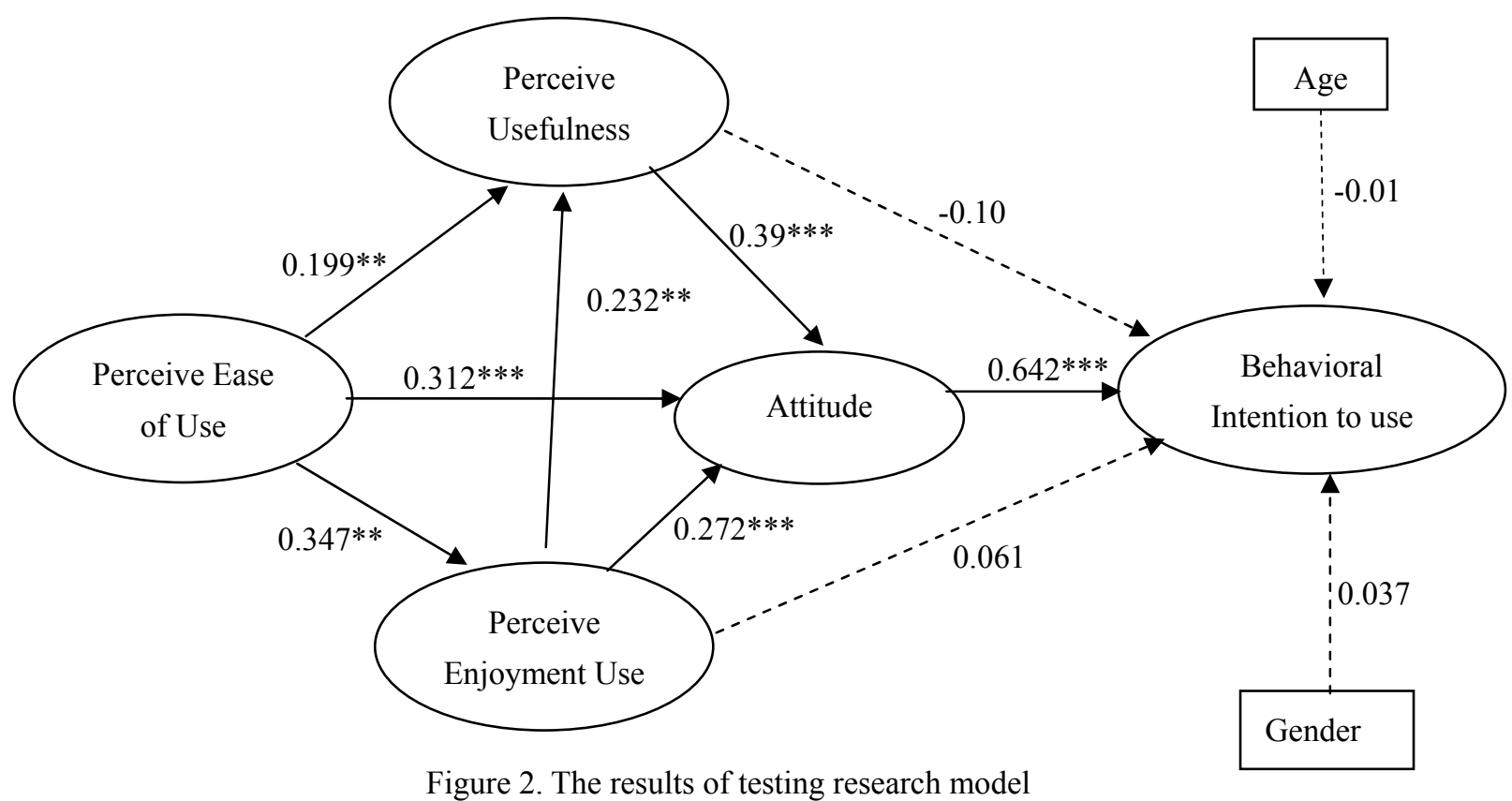

Note. $* * * \mathrm{p}<0.001$

In the final stage, the examination of SEM was implemented to test the hypothesized causal relationships within the research model. The results of fit statistics in SEM include: chi-square= 318.109; Chi-square/df $=1.160(<5)$; $\mathrm{CFI}=0.982(>0.9) ; \mathrm{GFI}=0.901(>0.9) ; \mathrm{TLI}=0.979(>0.9) ; \mathrm{RMSEA}=0.027(<0.08)$.

Figure 2 presents the results of SEM with standardized regression weights. The results show that PEOU has a positive relationship with PE, attitude and PU (these relationships' estimated coefficients $\beta=0.347, \beta=0.312$ and $\beta=0.199$ with the significant level at $1 \%$, respectively). PU and PE have positive impacts on attitude with $\beta=$ 0.39 and 0.272 , respectively. Finally, there is a strong correlation between attitude and BITU $(\beta=0.642)$. However, there is no difference from age and gender in BITU 3G mobile services.

Table 5 presents the results of testing hypotheses. As above results, only hypotheses 5 and 7 are rejected while the remaining hypotheses are accepted.

Table 5. Result of testing hypotheses

\begin{tabular}{ll}
\hline Hypotheses & Result of testing \\
\hline H1: PEOU positively affects PU of $3 G$ mobile services. & Supported \\
H2: PEOU has a positive effect on attitude towards using $3 G$ mobile services. & Supported \\
H3: PEOU has a positive impact on PE of $3 G$ mobile services & Supported \\
H4: PU positively affects attitude towards using $3 G$ mobile services. & Supported \\
H5: PU has a positive effect on BITU $3 G$ mobile services. & Not supported \\
H6: PE positively affects attitude towards using $3 G$ mobile services. & Supported \\
H7: PE has a positive impact on BITU $3 G$ mobile services. & Not supported \\
H8: PE has a positive effect on PU of $3 G$ mobile services. & Supported \\
H9: Attitude positively affects BITU $3 G$ mobile services & Supported \\
\hline
\end{tabular}

\section{Discussion}

At the beginning, hypothesis that PU of $3 \mathrm{G}$ is positively affected by PEOU is supported. This finding is consistent with the result in previous empirical studies, especially original research developing TAM model of Davis (1989). In addition, according to Figure 2, standardized regression weight of the direction shows that the estimated coefficient effect of PEOU on PE (0.347) is higher than that of PEOU on PU (0.279) and ATT (0.312). This implies that the easier usage of new technology, the more customers enjoy $3 \mathrm{G}$ mobile services. Therefore, it comes to concluding that a customer, who feels easy to access, operate and use $3 \mathrm{G}$ services, is likely to use more $3 \mathrm{G}$ more services. 
Like above relationship, positive relationships between PEOU and ATT, PU and ATT, PU and ATT, PU and BITU, ATT and BITU mentioned in H2, H3, H4, H5 and H8 are also supported by original TAM model of Davis (1989). In contrast, we find there is no direct effect of PU on BITU and not consistent with the finding in TAM of Davis (1989). However, some other studies (Liao et al., 2007; Kuo \& Yen, 2009) figure out the same findings which also do not support this hypothesis. This may imply that Vietnamese customers have not utilized the great applications and services of $3 \mathrm{G}$ technology. Clearly, according to descriptive statistics from this study, some useful applications and services such as video call, online music, online television, and so on accounted for a small percentage of applications from $3 \mathrm{G}$ mobile services, which refers that these $3 \mathrm{G}$ applications may be still not popular for $3 \mathrm{G}$ users. The explanation for this could be that Vietnamese $3 \mathrm{G}$ customers just focus on using traditional or familiar applications like chatting services or web-surfing, which makes up majority of $3 \mathrm{G}$ application usage. In addition, subscribers often choose a minimum package of $3 \mathrm{G}$ mobile services to save monthly charges. Therefore, with such a limited package of data transmission per month, $3 \mathrm{G}$ customers are more likely to avoid using online services with requiring huge data transactions. Specifically, the PE is positively associated with PU; the result is also consistent with that of Liao et al. (2007). This confirmed PE is a potentially essential variable to use $3 \mathrm{G}$ services.

The results of testing two hypotheses $\mathrm{H} 6$ and $\mathrm{H} 7$ also demonstrate interesting findings. Specifically, H6 proposing that PE positively affects ATT was supported and this echoes the finding of prior studies (Moon \& Kim, 2001; Van der Heijden, 2003; Bruner \& Kumar, 2005; Liao et al., 2007). Therefore, it concludes that more fun and exciting characteristics of 3G-based services or greater variety of them, which can encourage customers' curiosity and interest will make customers more willing to use 3G.

On the other hand, as comparing with the research model of Liao et al. (2007), it could be seen that there is a direct relationship between PE and BITU, meanwhile the result from our research model is unsupported because its p-value equal higher than criteria of 0.05 for statistical significance. However, there are some previous studies supporting this finding (Chong et al., 2010; Suki, 2011). One explanation for this could be that there is a lack of 3G-based services that customers really perceive and feel fun or enjoyable. In addition, the reason for explaining H5 mentioned above could explain this finding somehow. This reason is that $3 \mathrm{G}$ customers do not use various 3G-based applications and services so completely that they can experience really perceived usefulness and fun. They just focus on familiar or mostly-used services to satisfy their basic needs like web-surfing or chatting services due to high monthly fees of a larger package of data transmission.

\section{Conclusion and Implications}

\subsection{Conclusion}

This study investigated acceptance of the $3 \mathrm{G}$ mobile services by identifying the key factors which significantly affect $3 \mathrm{G}$ acceptance process. The study concluded that perceived ease of use, perceived usefulness and perceived enjoyment are all essential factors to attitude towards using $3 \mathrm{G}$ services. The findings are consistent with many previous studies conducted in other countries. Specifically, perceived ease of use has positive effects on perceived usefulness and perceived enjoyment. Finally, attitude is always a significant factor having a very strong impact on customer's BITU in acceptance process and the control variables of the demographic profiles such as age and gender have no significant effect on behavioral intention to use $3 \mathrm{G}$ mobile services.

\subsection{Managerial Implications}

In terms of practical aspects, this study also provides some implications. These implications can be applied by $3 \mathrm{G}$ providers in order to offer and improve more $3 \mathrm{G}$ services and value added contents for customers, especially young customers who are the main target in this study. The perceived usefulness and perceived ease of use still plays an important role in encouraging the positive attitude of customers towards using $3 \mathrm{G}$. For this reason, providers of $3 \mathrm{G}$ services should focus on drawing much attention of customers to notice potential and new benefits as well as easiness of operating 3G-based services in marketing especially in some special presentation events such as technology fairs and technology exhibitions to give more opportunities for customers to experience $3 \mathrm{G}$ services directly. The ease of use is a vital dimension to the process of adoption. Existing and potential customers will always be willing to use a variety of $3 \mathrm{G}$ mobile services if they are easy to use and one important point is that when they access these services easily they soon discover the benefits and fun or enjoyment in application or services, which lead them to feel good attitude. Besides, providers of $3 \mathrm{G}$ should care about the fun and enjoyment of $3 \mathrm{G}$ services and application by designing and developing interesting and entertaining contents with appropriate subscribing and usage fees. According to the opinions during the survey from respondents, they also suggested that $3 \mathrm{G}$ providers could improve transmission speed and reduce the usage fees of $3 \mathrm{G}$ to make $3 \mathrm{G}$ services worthy and easy to use for customers. Finally, to improve consumers' behavioral 
intention adopting $3 \mathrm{G}$ for mobile phone, attitude should be the main focus of providers of 3G. Providers themselves need to focus on listening and receiving customers' feedbacks via technical support centers or customer service centers to improve and offer more value added services for customers.

\subsection{Limitations}

The first limitation is that majority of the number of respondents are undergraduate students. It means that the results from the study could not be used in order to generalize all customers. For this reason, a future study could target diversity of subjects with different backgrounds or demographic characteristics, which makes results of research more convincing and easier to generalize and conclude.

Secondly, the proposed research model is still simple with original factors in TAM model and it does not cover many complex or potential factors, which can involve in the adoption process. Therefore, future research could add other factors, which have been so newly potential and have just been explored in very few recent relevant researches such as network effects, personal innovativeness, cost, service quality and trust. In addition, a further study should emphasize on the different characteristics between information technology and $3 \mathrm{G}$ so that they can apply the research model more practically.

\section{References}

Adams, D. A., Nelson, R. R., \& Todd, P. A. (1992). Perceived usefulness, ease of use, and usage of information technology: A replication. MIS Quarterly, 16, 227-247. http://dx.doi.org/10.1016/2Fj.jbi.2009.06.001

Agarwal, R., \& Prasad, J. (1997). The Role of Innovation Characteristics and Perceived Voluntariness in the Acceptance of Information Technologies. Decision Sciences, 28(3), 557-558 http://dx.doi.org/10.1111/j.1540-5915.1997.tb01322.x

Ajzen, I., \& Fishbein, M. (1980). Understanding attitudes and predicting social behavior. Englewood Cliffs, NJ: Prentice-Hall.

Anderson, J. C., \& Gerbing, D. W. (1984). The effect of sampling error on convergence, improper solutions, and goodness-of-fit indices for maximum likelihood confirmatory factor analysis. Psychometrika, 49(2), 155-173. http://dx.doi.org/10.1007/BF02294170

Bruner II, G. C., \& Kumar, A. (2005). Explaining consumer acceptance of hand-held Internet devices. Journal of Business Research, 58(5), 553-558 http://dx.doi.org/10.1016/j.jbusres.2003.08.002

Burton-Jones, A., \& Hubona, G. S. (2005). Individual differences and usage behavior: Revisiting a technology acceptance model assumption. Database for Advances in Information Systems, 36(2), 58-77. http://dx.doi.org/10.1145/1066149.1066155

Campbell, \& Schwartz. (2001). Special issue on wireless extensions to the Internet. ACM SIGCOMM Computer Communication Review, 31(5), October 2001, 20-24. http://dx.doi.org/10.1145/1037107.1037111

Chen, L., Gillenson, M. L., \& Sherrell, D. (2002). Enticing online consumers: An extended technology $\begin{array}{llll}\text { acceptance perspective. Information \& } & \text { Management, } & 39(8), & \text { 705-719. }\end{array}$ http://dx.doi.org/10.1016/S0378-7206(01)00127-6

Chong, A. Y. L., Darmawan, N., Ooi, K. B., \& Lee, V. H. (2010). Determinants of 3G adoption in Malaysia: A structural analysis. Journal of Computer Information Systems, 51(2), 71-80.

Chong, A. Y. L., Ooi, K. B., Lin, B., \& Bao, H. (2012). An empirical analysis of the determinants of 3G adoption in China. Computers in Human Behavior, 28(2), 360-369. http://dx.doi.org/10.1016/j.chb.2011.10.005

Dabholkar, P. A., \& Bagozzi, R. P. (2002). An attitudinal model of technology-based self-service: Moderating effects of consumer traits and situational factors. Journal of the Academy of Marketing Science, 30(3), 184-201 http://dx.doi.org/10.1177/0092070302303001

Davis, F. D. (1989). Perceived usefulness, perceived ease of use, and user acceptance of information technology. MIS Quarterly, 13(3), 319-340. http://dx.doi.org/10.2307/249008

Davis, F. D., Bagozzi, R. P., \& Warshaw, P. R. (1989). User acceptance of computer technology: A comparison of two theoretical models. Management Science, 35, 982-1002. http://dx.doi.org/10.1287/mnsc.35.8.982

George, D., \& Mallery, P. (2003). SPSS for Windows step by step: A simple guide and reference. 11.0 update (4th ed.). Boston: Allyn \& Bacon.

Hair, J. F., Jr., Anderson, R. E., Tatham, R. L., \& Black, W. C. (1998). Multivariate data analysis (5th ed.). Upper Saddle River, NJ: Prentice Hall. http://dx.doi.org/10.1137/ S0036144598347035 
Hung, S. Y., Ku, C. Y., \& Chang, C. M. (2003). Critical factors of WAP services adoption: An empirical study. Electronic Commerce Research and Applications, 2(1), 46-60. http://dx.doi.org/10.1016/S1567-4223(03)00008-5

Igbaria, M., Livari, J., \& Maragahh, H. (1995). Why do Individuals Use Computer Technology? A Finnish Case Study. Information and Management, 5, 227-238 http://dx.doi.org/10.1016/0378-7206(95)00031-0

Igbaria, M., Schiffman, S. J., \& Wieckowaki, T. J. (1994). The respective roles of perceived usefulness and perceived fun in the acceptance microcomputer technology. Behaviour \& Information Technology, 13(6), 349-61. http://dx.doi.org/10.1080/01449299408914616

Igbaria, M., Zinatelli, N., Cragg, P., \& Cavaye, A. L. M. (1997). Personal computing acceptance factors in small firms: A structural equation model. MIS Quarterly, 21(3), 279-305. http://dx.doi.org/10.2307/249498

Kuo, Y. F., \& Yen, S. N. (2009). Towards an Understanding of the Behavioral Intention to Use 3G Mobile Value-Added Services. Computers in Human Behavior, 25, 103-110. http://dx.doi.org/10.1016/j.chb.2008.07.007

Lemmens, J. (2010). Student's readiness for university education (Unpublished doctoral thesis). University of Pretoria, Pretoria, South Africa.

Liao, C. H., Tsou, C. W., \& Huang, M. F. (2007). Factors influencing the usage of 3G mobile services in Taiwan. Online Information Review, 31(6), 759-774. http://dx.doi.org/10.1108/14684520710841757

Moon, J. W., \& Kim, Y. G. (2001). Extending the TAM for a world-wide-web context. Information \& Management, 38(4), 217-230. http://dx.doi.org/10.1016/S0378-7206(00)00061-6

Pagani, M. (2004). Determinants of adoption of third generation mobile multimedia services. Journal of Interactive Marketing, 18(3), 46-59. http://dx.doi.org/10.1002/dir.20011

Pallant, J. (2007). SPSS Survival Guide: A step by step guide to data analysis using SPSS Version 15. London: Open University Press.

Robinson, L., Marshall, G. W., \& Stamps, M. B. (2005). Sales force use of technology: Antecedents to technology acceptance. Journal of Business Research, 58(12), 1623-1631. http://psycnet.apa.org/doi/10.1016/j.jbusres.2004.07.010

Slater, S. (1995). Issues in Conducting Marketing Strategy Research. Journal of Strategic Marketing, 3(4), 257-270. http://dx.doi.org/10.1080/09652549500000016

Suki, N. (2011). Factors Affecting Third Generation (3G) Mobile Service Acceptance: Evidence from Malaysia. Journal of Internet Bankinzg and Commerce, 16(1), 1-12. http://dx.doi.org/10.5897/AJBM11.281

Teo, T. S., \& Pok, S. H. (2003). Adoption of WAP-enabled mobile phones among Internet users. Omega, 31(6), 483-498. http://dx.doi.org/10.1016/j.omega.2003.08.005

Thompson, R. L., Higgins, C. A., \& Howell, J. M. (1991). Personal computing: Toward a conceptual model of utilization. MIS Quarterly, 15(1), 124-143. http://dx.doi.org/10.2307/249443

Van Der Heijden, H. (2003). Factors influencing the usage of websites: The case of a generic portal in the $\begin{array}{lllll}\text { Netherlands. Information } \quad \& \quad \text { Management, } & 40(6), & \text { 541-549 }\end{array}$ http://dx.doi.org/10.1016/S0378-7206(02)00079-4

Van Der Heijden, H. (2004). User acceptance of hedonic information systems. MIS Quarterly, 28, 695-704.

Venkatesh, V. (2000). Determinants of perceived ease of use: integrating control, intrinsic motivation, and emotion into the technology acceptance model. Information System Research, 4(4), 342-365. http://dx.doi.org/10.1287/isre.11.4.342.11872

Vijayasarathy, L. R. (2004). Predicting consumer intentions to use on-line shopping: The case for an augmented technology acceptance model. Information \& Management, 41(6), 747-762. http://dx.doi.org/10.1016/j.im.2003.08.011

Yang, K. C. C. (2005). Exploring factors affecting the adoption of mobile commerce in Singapore. Telematics and Informatics, 22(3), 257-277. http://dx.doi.org/10.1016/j.tele.2004.11.003

Yu, J., Ha, I. Choi, M., \& Rho, J. (n.d). Extending the TAM for a t-commerce. Information \& Management, 42(7), 965-976. http://dx.doi.org/10.1016/j.im.2004.11.001 


\section{Copyrights}

Copyright for this article is retained by the author(s), with first publication rights granted to the journal.

This is an open-access article distributed under the terms and conditions of the Creative Commons Attribution license (http://creativecommons.org/licenses/by/3.0/). 